\title{
Recorregut de recerca geològica i mineralògica per la comarca del Solsonès: des de Solsona i Olius, cap a Besora i a Busa
}

Josep Maria Mata-Perelló

Joaquim Sanz Balagué

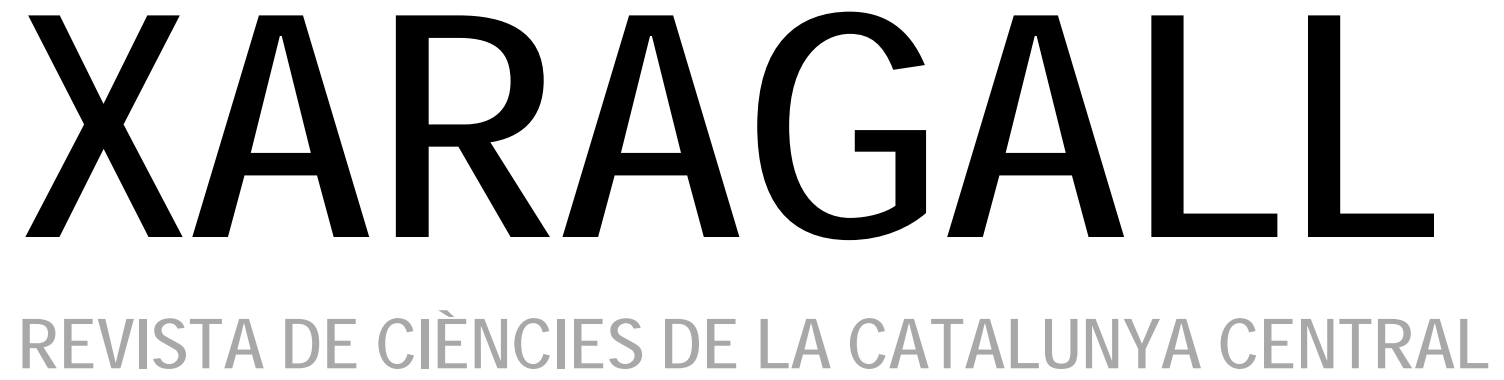

ก. 5

MAIG 2015 


\section{RECORREGUT DE RECERCA GEOLÒGICA I MINERALÒGICA PER LA COMARCA DEL SOLSONĖS: DES DE SOLSONA I OLIUS, CAP A BESORA I A BUSA}

\section{Josep Maria Mata-Perelló}

Museu de geologia Valentí Masachs, Escola Politècnica Superior d'Enginyeria de Manresa (EPSEM), Universitat Politècnica de Catalunya · BarcelonaTech (UPC), 08272 Manresa, Spain

\section{Joaquim Sanz Balagué}

Departament d'Enginyeria Minera i Recursos Naturals (EMRN), Escola Politècnica Superior d'Enginyeria de Manresa (EPSEM), Universitat Politècnica de Catalunya . BarcelonaTech (UPC), 08272 Manresa, Spain

Paraules clau: Depressió Geològica de l'Ebre, Patrimoni miner

\section{Resum}

Itinerari realitzat el 7 de juny de 2014. En aquesta ocasió, el recorregut del present itinerari discorrerà per una de les tres unitats geològiques que constitueixen Catalunya: concretament per la Depressió Geològica de l'Ebre.

Així, ho farà en bona part per un dels sectors que la constitueixen (MATA-PERELLÓ, 1985): exactament per la seva Depressió Central i pels sectors corresponents als Altiplans Septentrionals.

Així, el recorregut començarà a la localitat de Solsona, continuant-se després cap als termes municipals d'Olius i Navès, finalitzat a la Serra de Busa. 


\section{Objectius fonamentals}

Els objectius fonamentals que es pretenen aconseguir en aquest itinerari, es poden concretar en els següents aspectes generals:

1. Observació i descripció dels materials terciaris eocènics i oligocènics de la Depressió Geològica de l'Ebre, que constitueixen el subsòl de la comarca del Solsonès, pels indrets per on transcorre l'itinerari. En concret ens referirem als materials de la Formació Solsona i els de la Formació Berga.

2. Observació de les estructures locals d'aquests materials, al llarg del recorregut de I'itinerari, com el Sinclinal de Solsona; així com I' Anticlinal del Cap de Costa., tat i que aquest darrere a més distància. Per d'altra banda, cap a la fi del recorregut es veurà el Sinclinal de Busa, situat per sobre de la discordança progressiva de Busa - Bastets.

3. Observació, a distancia dels materials mesozoics (del Triàsic, Juràssic i Cretàcic), els quals formen part del Mantell del Cadí i del Mantell Inferior del Pedraforca, de la Zona Sudpirinenca. Tanmateix, veurem els afloraments cenozoics eocènics de la Formació Cadí, els quals formen part del primer mantell acabat d'esmentar.

4. Visió de les relacions existents entre la Zona Sudpirenenca i la Depressió Geològica de I'Ebre. Això es podrà observar per les immediacions de la Serra de Busa, tot i que a distancia.

5. Observació i reconeixement de diferents mineralitzacions situades a diversos indrets del recorregut de l'itinerari.

6. Observació de les diferents explotacions dels georecursos, i en especial dels corresponents a les formacions salines.

7. Observació dels impactes produïts sobre el Medi Ambient, i sobre el Medi Natural, per part de les explotacions abans esmentades.

8. Observació dels nombrosos exemples dels típics relieves en cuesta, desenvolupats fonamentalment entre els materials cenozoics, a través del recorregut de l'itinerari.

9. Observació dels diferents elements relacionats amb el Patrimoni Miner i amb el Patrimoni Natural, que anirem trobant al llarg de tot el recorregut del present itinerari. 


\section{Antecedents}

Existeixen diferents antecedents bibliogràfics en relació al recorregut d'aquest itinerari. Així, entre aquests, farem esment dels següents: MASACHS et altri (1981), MATA-PERELLÓ (1991a, 1995, 1997a, 1997b, 1997, 1998, 1999a, 199b, 2005 i 2010). Molts d'elles coincideixen en alguns trams amb el que ara presentem.

Per altra banda, i pel que fa a les mineralitzacions existents, a la comarca del Bages, ens remetin a altres treballs també nostres; concretament a: MATA-PERELLÓ $(1990,1991 \mathrm{~b}$ i 1994), i també a MATA-PERELLÓ i COLLDEFORNS (1993).

I finalment, pel que correspon als treballs geològics de caràcter general, ens hem de referir necessàriament a les publicacions de: COLLDEFORNS (1986), GUIMERÀ et altri (1992), i RIBA et altri (1976). I també als treballs de I'IGME (1975 i 1982).

Tots aquests treballs acabats d'esmentar, figuren relacionats per ordre alfabètic a l'apartat de REFERÈNCIES BIBLIOGRÀFIQUES.

\section{Recorregut de l'itinerari}

El recorregut del present itinerari, s'inicia a la localitat de Solsona, per on es farà la primera aturada. Després el recorregut s'encaminarà cap a Olius, per on es farà una nova aturada. Poc després, ens caldrà agafar el camí - carreter que es dirigeix cap a Besora i cap a Busa. En arribar a aquest darrer lloc finalitzarà l'itinerari, després de fer-se les darreres aturades.

\section{Advertiments previs}

Com en altres recorreguts de RECERCA GEOLÒGICA I MINERALÒGICA... si es disposa del temps suficient, poden efectuar-se passant per totes les parades i filloles. En cas contrari, recomanem prescindir de les anomenades PARADES - CONDICIONALS.

Com de costum, creiem oportú de recomanar, que alhora d'efectuar el recorregut de l'itinerari es cerqui la informació més àmplia possible sobre l'estat dels trams del recorregut a realitzar, tant per pistes forestals, com per carreteres en mal estat de conservació. En aquest itinerari, hi ha pocs trams que s'hagin d'efectuar en aquestes circumstàncies. Aquest és el cas del camí d'accés a Busa.

També, per altra banda, en qualsevol cas, i en tot moment (tant dintre del recorregut de l'itinerari, com fora d'ell), recomanem tenir el màxim respecte per al Medi Natural que ens envolta. 


\section{Descripció de l'itinerari}

Com ja es habitual, s'estructurarà en una sèrie d'estacions (parades o aturades), en les qual es faran descripcions geològiques o mineralògiques, segons s'escaigui. En cada parada s'indicarà el número del mapa topogràfic a escala 1:50.000 on es troba l'indret. Per això, s'utilitzarà la cartografia editada per I'"Instituto Geográfico y Catastral de España". En aquest cas, el recorregut de l'itinerari passarà per part dels dos següents fulls: 330 (també anomenat de Cardona) i 292 (o de Sant Llorenç de Morunys).

Així doncs, la relació general i ordenada, de les aturades que composen el recorregut d'aquest itinerari, és la següent:

\subsection{Parada 1. IMMEDIACIONS DE L'HOTEL GRAN SOL, (terme municipal de Solsona, comarca del Solsonès). (Full 330).}

El recorregut de l'itinerari el començarem a la localitat solsonina de Solsona (la seva capital comarcal). Just al seu inici, pels voltants de I'Hotel Gran Sol, ja podem fer la primera aturada del recorregut de l'itinerari.

Aquest indret (així com tota la ciutat de Solsona), es troba situat dintre de la Depressió Geològica de l'Ebre; i més concretament dintre de la denomina Depressió Central; això és, dintre dels sectors centrals de la també denominada Conca Geològica de l'Ebre així, per arreu, es veuen afloraments dels materials cenozoics de la Formació Solsona. Es tracta de nivells de calcolutites i gresos, de tonalitats ocres, procedents del Sistema Pirinenc, els quals han reblerts la depressió. Cal dir que aquestes tonalitats venen de la presencia de limonita, la qual comunica el color bru als altres minerals (incolors) de les roques abans esmentades.

Des d'aquest indret, es fa palès el flanc meridional del Sinclinal de Solsona. Es tracta d'un sinclinal molt lax, però el seu flanc es fa força pales i correspon a la superfície del terreny, baixant des del Pi de Sant Just cap a Solsona. L'altre flanc no el podem veure; el trobaríem en cas de fer un recorregut cap a Lladurs, al Nord de Solsona.

\subsection{Parada 2. CERÀMICA MAPSA (terme municipal de Solsona, comarca del Solsonès). (Full 330).}

Des de la parada anterior, cal continuar breument cap el Sud, per la carretera $C-55$, la qual es dirigeix cap a Manresa. A uns $3 \mathrm{Km}$ de Solsona, trobarem una antiga fàbrica de ceràmica, per on podem fer una nova aturada.

En aquest recorregut hem continuat trobant afloraments dels nivells de gresos i de calcolutites ocres, els quals pertanyen a la Formació Solsona. Per d'altra banda, en aquest indret es troba una fàbrica de ceràmica, i a uns $200 \mathrm{~m}$ de la mateixa, a la dreta de la carretera, hi ha l'explotació de la matèria prima que abasteix aquesta indústria. Es tracta d'un aflorament de nivells margosos, els quals es troben intercalats entre altres de gresos. Uns i altres pertanyen a denominada Formació Solsona. 


\subsection{Parada 3. TRENCALL D'OLIUS, (terme municipal d'Olius, comarca del Solsonès). (Full 330).}

Després de fer l'aturada anterior, cal retornar lleugerament cap enrere, fins arribar a la cruïlla amb la carretera C - 26. En trobar-la, caldrà agafar-la, per tal d'anar cap a llevant. En arribar a les immediacions d'Olius farem una nova aturada.

En passar per prop de la ciutat es travessa el pla axial del Sinclinal de Solsona (MASACHS et altri, 1981). Es tracta d'un accident molt lax, amb un cabussament gairebé horitzontal. Poc després es van trobant els materials amb una lleugera inclinació cap el sud, constituint el flanc septentrional del sinclinal.

En aquest recorregut hem continuat trobant afloraments dels nivells de gresos i de calcolutites ocres, els quals pertanyen a la Formació Solsona. Així, a l'indret de l'aturada, es poden veure aquests materials, de tonalitats ocres. (fotografia 1 ).

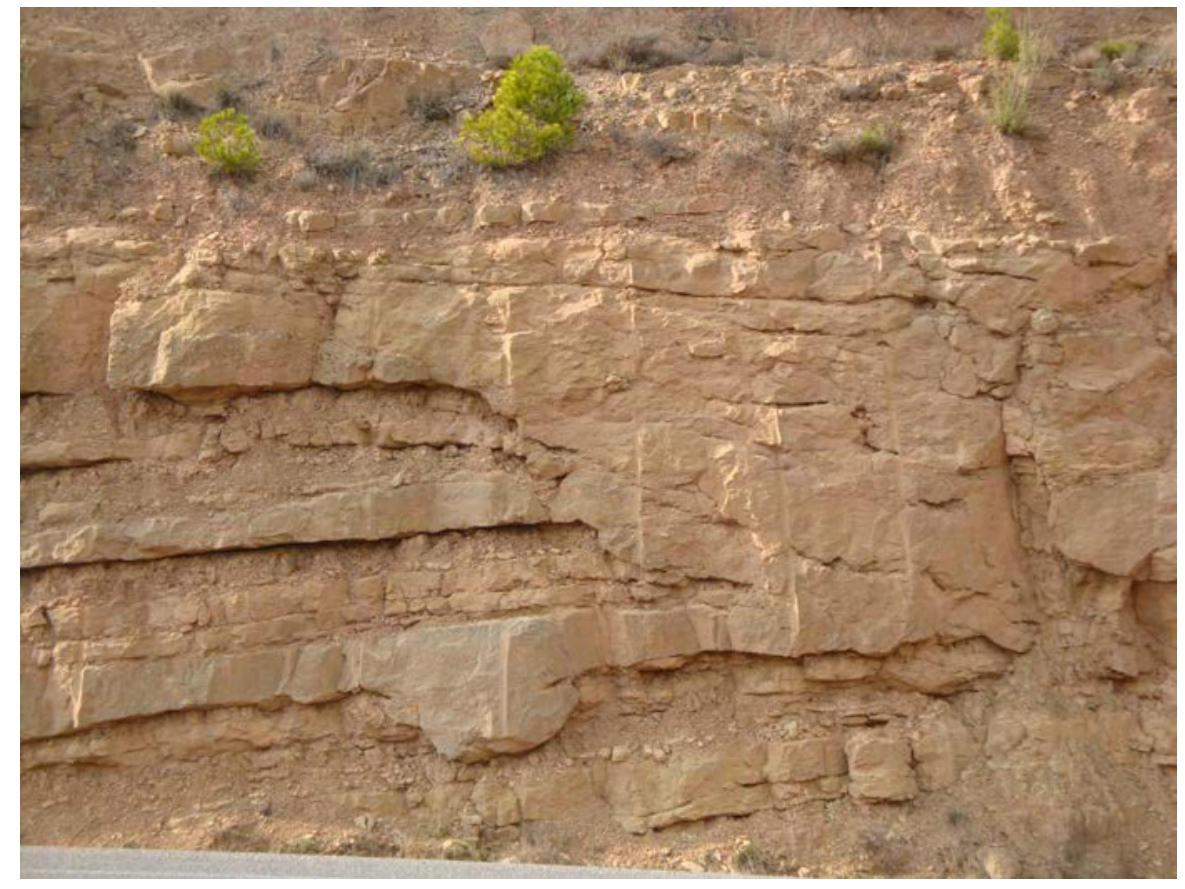

Fotografia 1. Aflorament dels materials de la Formació Solsona, prop d'Olius

Cal dir que les tonalitats ocres procedeixen de la presencia de Limonita (en concret del seu mineral GOETHITA) entre els sediments abans esmentats: gresos i calcolutites. Com que la resta dels minerals són incolors, el mineral de ferro abans esmentat, els hi comunica les seves tonalitats ocres i brunes. 


\subsection{Parada 4. GUIXERA DE BESORA, (Besora, terme municipal de Navès, comarca del Solsonès). (Full 292).}

Poc després de sobrepassar Olius, haurem de continuar cap a Navès. Abans d'arribar a aquest darrer poble, trobarem un camí - carreter que es dirigeix cap a Besora. Poc després de superar aquest llogarret, continuant ara cap a Busa, trobarem una antiga guixera, on podem fer una nova aturada, a uns $5 \mathrm{Km}$ de l'anterior.

En aquest recorregut, hem continuat trobant els materials cenozoics de la Formació Solsona, que molt sovint son detrítics. Tot i així, en aquest indrets es fan palesos uns nivellets de guix que han estat explotats en una antiga i petita guixera.

\subsection{Parada 5. IMMEDIACIONS DE CA N’ORDIGUESA, (Busa, terme municipal de Navès, comarca del Solsonès). (Full 292).}

Poc després de sobrepassar Besora, haurem de continuar cap a Busa, que ja es va veient a lo lluny. En arribar prop del Collet de Ca n'Ordiguesa, al peu de la cinglera farem una nova aturada, a uns $8 \mathrm{Km}$ de la parada anterior.

En aquest recorregut, hem anat trobant els materials abans esmentats de la Formació Solsona. Aquests materials són cada com més detrítics, conglomeràtics, formant part dels mantells postectònics. Així, ara estem entre afloraments de la Formació Berga.

Per altra banda, des d'aquest lloc es pot veure la gran cinglera de Busa, delimitada pels nivells de conglomerats que acabem d'esmentar. (fotografia 2).

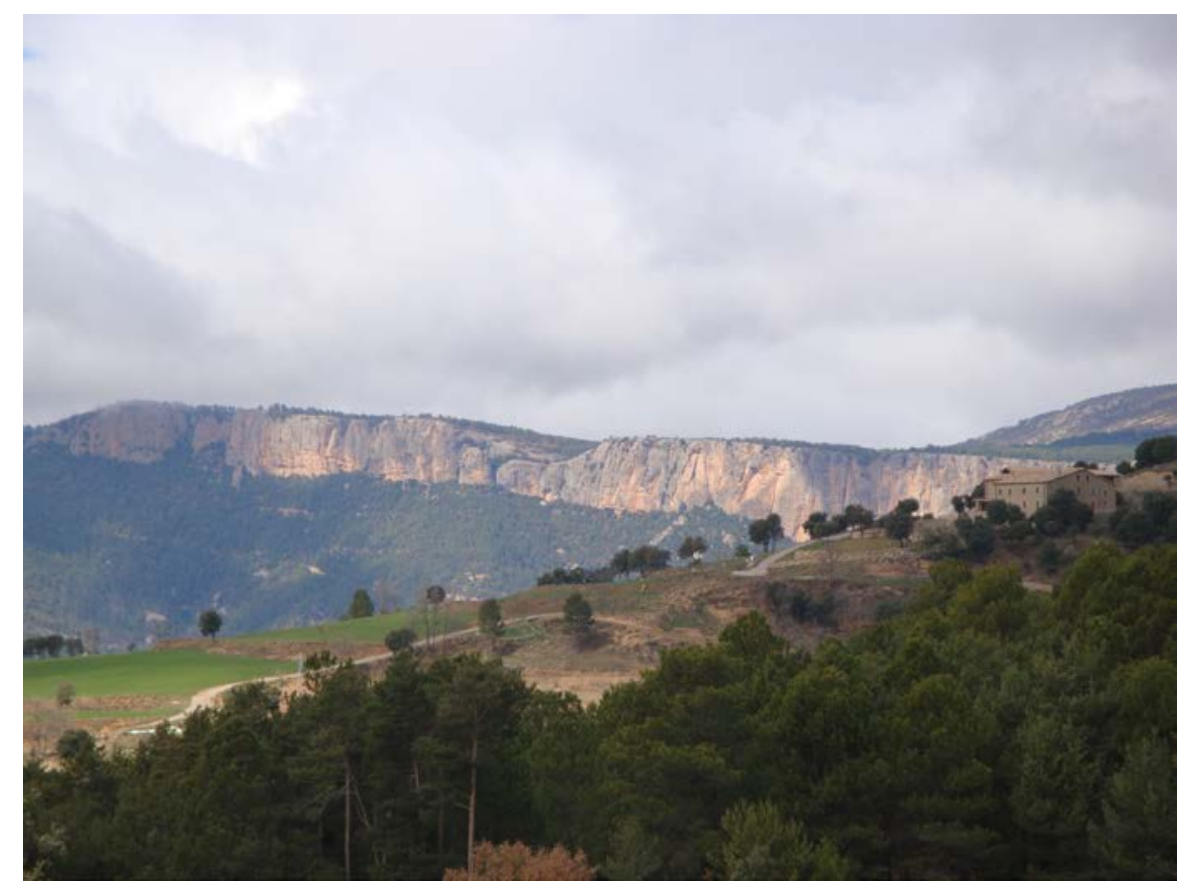

Fotografia 2. Observació del penya segat de Busa, des de llevant d'on ara som, des de Sant Lleir 


\subsection{Parada 6. PLA DE BUSA, (Busa, terme municipal de Navès, comarca del Solsonès). (Full 292).}

Després de fer l'aturada anterior, ens cal pujar cap a Busa, pel camí que discorre per la cinglera. En arribar a dalt farem una nova aturada, a uns $2 \mathrm{Km}$ de la parada anterior. Cal tenir en compte que aquest tram no es troba normalment en bones condicions.

En aquest recorregut hem arribat al pla de Busa, després de travessar la cinglera on afloren els materials conglomeràtics de la Formació Berga. Tot i aquesta costa, en arribar a dalt apareix un gran pla. Aquest no és altra cosa que la cubeta d'un gran sinclinal, molt lax: el Sinclinal de Busa. Ara precisament, ens trobem al bell mig del mateix. (fotografía 3).

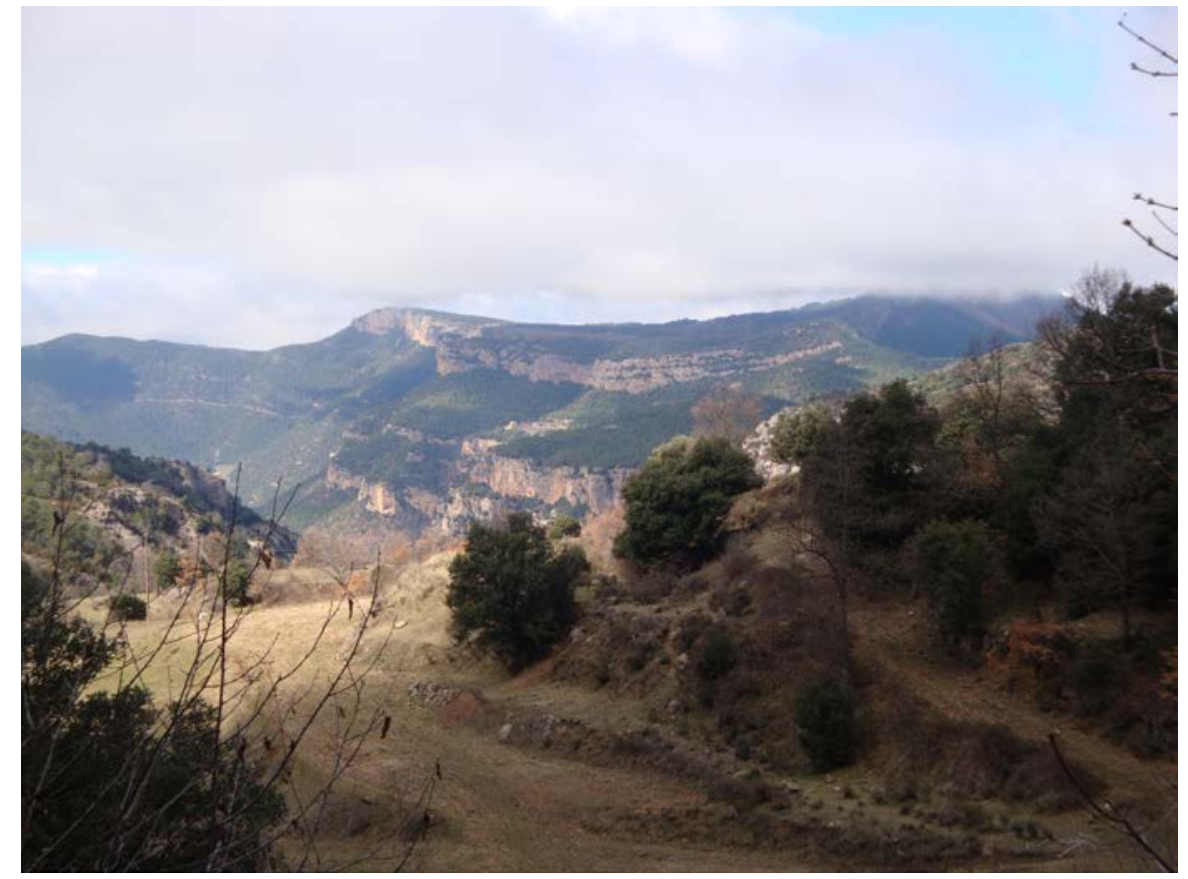

Fotografia 3. Un aspecte llunyà del Sinclinal de Busa, des de llevant, des de la Vilella

\subsection{Parada 7. CINGLE DE L'ARENY, (Busa, terme municipal de Navès, comarca del Solsonès). (Full 292).}

Després de fer l'aturada anterior, ens cal anar cap al ponent del pla, cap a les immediacions del Cingle de l'Areny. Aquí farem la darrera aturada, a poca distancia de l'anterior, a gairebé 1 '5 $\mathrm{Km}$ del Caseriu de Busa.

En aquest recorregut, ens haurem mogut pel Sinclinal de Busa, arribant ara a la vorera de la costa. Així, des d'aquest lloc enlairat, es pot gaudir d'una bona vista, mirant cap el Nord i cap el NW. (fotografies 4 i 5). 


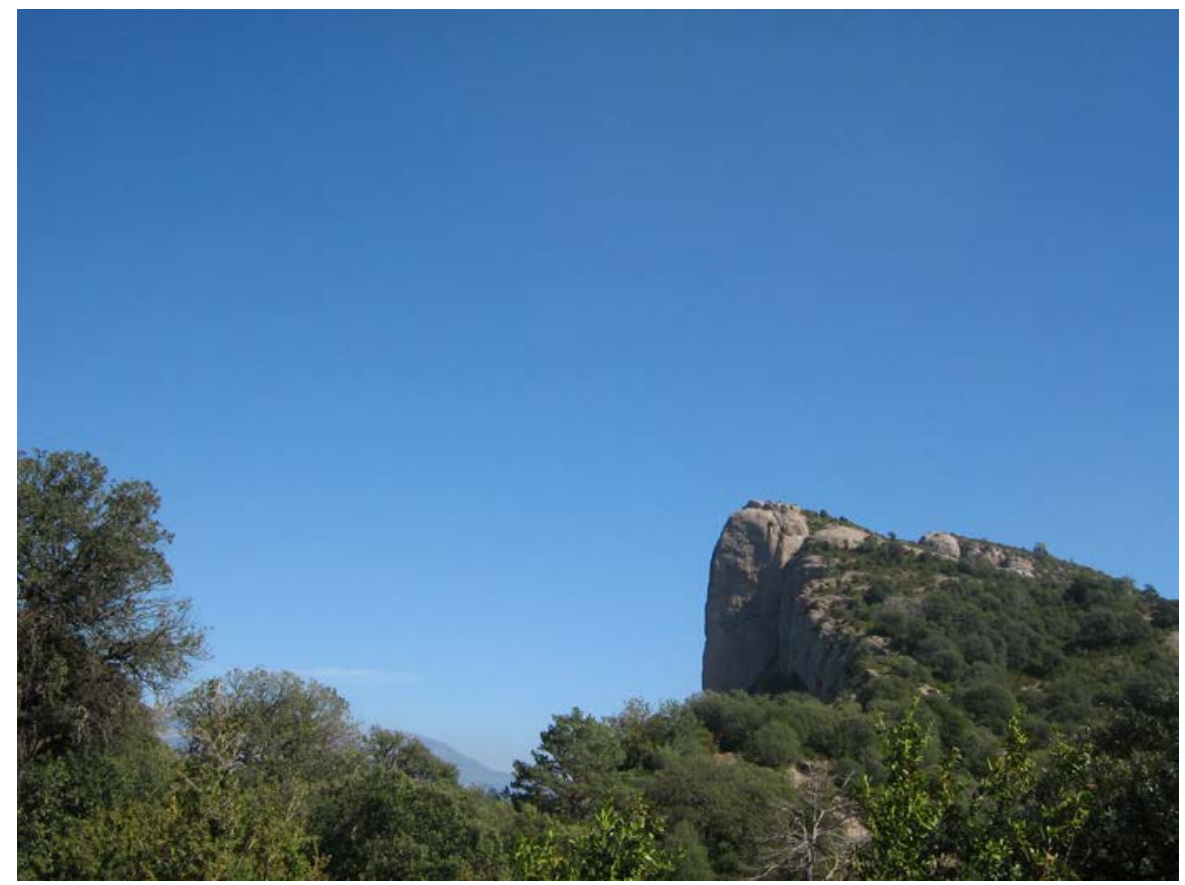

Fotografia 4. Cingle de l'Areny. Aflorament dels conglomerats de Berga. Busa

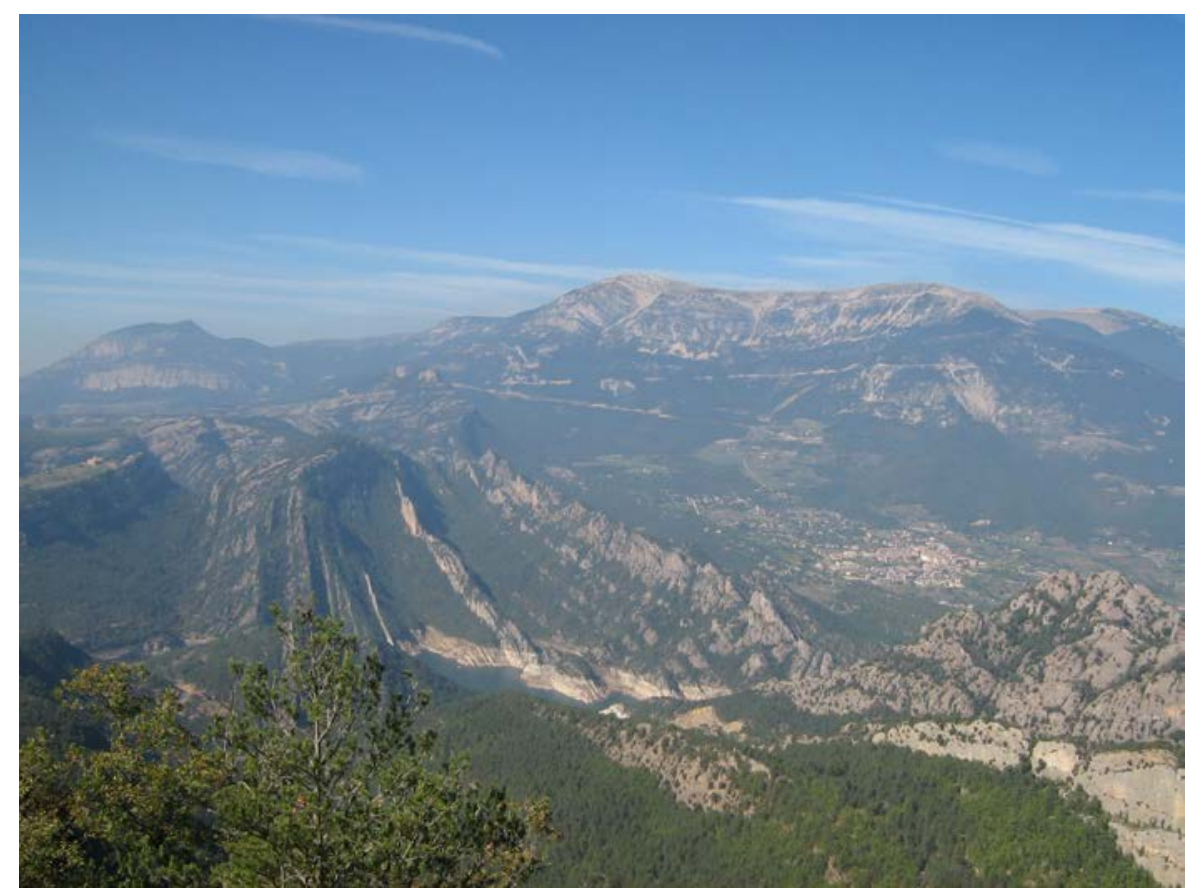

Fotografia 5. Sinclinal del Llord, discordança progressiva de Codó i Serra del port de Comte. Des de Busa 
Així, es pot entreveure la discordança progressiva de Busa - Bastets. Així, cap al Nord es poden veure, als peus de Busa, els materials verticalitzats de Bastets, que poc a poc es van inclinant, fent-se gairebé horitzontals a Busa, on ara som.

Tanmateix es pot veure el Sinclinal del Llord (molt similar al de Busa, on ara som), discordança progressiva de Codó i fins i tot la Serra del Port de Compte, al Nord de la discordança anterior.

\subsection{Parada 8. LA PRESÓ DE BUSA, (Busa, terme municipal de Navès, comarca del Solsonès). (Full 292).}

Després de fer l'aturada anterior, cal fer un breu recorregut, anant cap a ponent. A uns 300 metres a peu, podem fer la darrera aturada del recorregut d'aquest itinerari.

En aquest recorregut, hem anat trobant els materials esmentats a les aturades anteriors. Aquests materials són també els que apareixen a l'indret de la present aturada. Així, per arreu, veurem afloraments dels materials de la Formació Berga, dels nivells de conglomerats que la constitueixen.

En aquest indret, separada per un diàclasi erosionada, ha quedat un sector de la Serra de Busa, separat de la resta. Pot anar-se d'una par a l'altra per una passarel.la. Aquest sector separat és l'anomenada Presó de Busa. (fotografía 6).

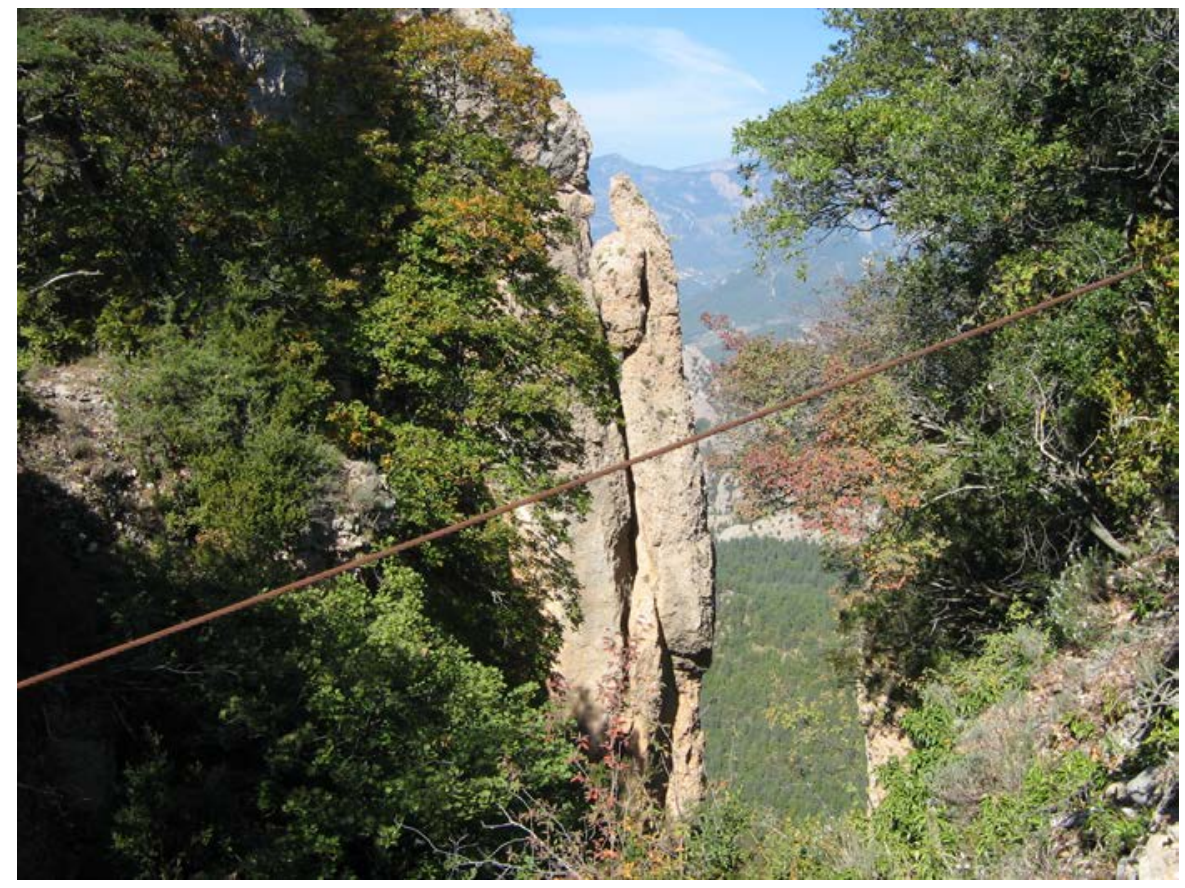

Fotografia 6. L’escletxa que separa la Presó de Busa del resta de la Serra de Busa 
En aquest indret finalitza el recorregut de l'itinerari

\section{Bibliografia}

COLLDEFORNS, B. (1986).- Estudi geològic del Bages, Inèdit, 385 pàgines. Sant Vicenç de Castellet.

GUIMERÀ, J. et altri (1992).- Geologia (II), Història Natural dels Països Catalans, Vol. 2, 547 pag. Enciclopèdia catalana, S.A., Barcelona.

IGME (1975).- Mapa Geológico de España a Escala 1:50.000 (2a Sèrie). Full i Memòria nº $\underline{330}$ (Cardona). Inst. Tecnológico y GeoMinero de España. Minist. Indus. Ener. Madrid

IGME (1982).- Mapa Geológico de España a Escala 1:50.000 (2a Sèrie). Full i Memòria no $\underline{362}$ (Calaf). Inst. Tecnológico y GeoMinero de España. Minist. Indus. Ener. Madrid.

MASACHS, V. et altri (1981).- Itineraris geològics per Anoía, Bages, Berguedà i Solsonès. Pub. Caixa d'Estalvis de Manresa, 205 pag. Manresa.

MATA-PERELLÓ, J.M. (1984).- Depressió Central o Depressió de I’Ebre, Revista Dovella, nº 36, pp 85-89. Manresa.

MATA-PERELLÓ, J.M. (1991a).- Selecció d'itineraris geològico-mineralògics: del Vallès Oriental a I'Alt Camp i al Solsonès. Revista Xaragall, n² 26, 42 pag. Manresa.

MATA-PERELLÓ, J.M. (1991b).- Els Minerals de Catalunya. Arxius de la Secció de Ciències, $t$. XCIII. 442 pàgines, Institut d'Estudis Catalans. Barcelona.

MATA-PERELLÓ, J.M. (1994).- Inventari Mineralògic de la comarca del Solsonès. Xaragall, 14, 30 pàgines. Manresa.

MATA-PERELLÓ, J.M. (1995a).- Itinerari geològic-mineralògic pel Bages: des de Manresa a Santpedor, a Súria i a Cardona. inèdit. 14 pàgines. Manresa.

MATA-PERELLÓ, J.M. (1995b).- Recerca a través de la geografia física de set comarques de la Catalunya Central. Pub. Museu de Geología de la UPC, 168 pàgines. Manresa.

MATA-PERELLÓ, J.M. (1997a).- Recorregut de recerca geològica i mineralògica per les comarques del Bages, del Solsonès i de la Segarra: des de la Coromina a Solsona, Torà de Riubregòs i a Iborra. Inèdit, 10 pàgines, Manresa.

MATA-PERELLÓ, J.M. (1997b).- Recerca geològica i mineralògica per les comarques del Solsonès i de I'Alt Urgell: des de Solsona al Coll de Jou i al Coll de Port. Inèdit. 10 pàgines. Manresa.

MATA-PERELLÓ, J.M. (1998).- Recorregut de recerca geològica i mineralògica per les comarques del Bages i del Solsonès: des de Súria a Cardona i a Solsona.Inèdit 12 pag. Manresa.

MATA-PERELLÓ, J.M. (1999).- Recorregut de recerca geològica i mineralògica per les comarques del Bages i del Solsonès: des de Súria cap a Cardona, Solsona i cap al Port del Compte. Inèdit, 15 pag. Manresa. 
MATA-PERELLÓ, J.M. (2005).- Recorregut de recerca geològica i mineralògica per les comarques del Bages i del Solsonès: des de Cardona, cap a Solsona i cap al Port del Compte, Inèdit. 10 pàg. Manresa.

MATA-PERELLÓ, J.M. (2010).- Recorregut de recerca geològica i mineralògica per les comarques del Bages i del Solsonès: des de Cardona, cap a Solsona i cap a Busa. Inèdit. 8 pàgines. Manresa.

MATA-PERELLÓ, J.M. i COLLDEFORNS, B, (1993).- Inventari Mineralògic de la comarca del Bages, Xaragall, $n^{\circ} 23,36$ pàgines. Manresa.

RIBA ARDERIU, O. (1967).- Resultados de un estudio sobre el terciário continental de la parte Este de la Depresión Central Catalana. Acta Geológica Hispánica, t.. 2, Vol.1, pp. 3-8. Barcelona.

RIBA ARDERIU, O. Et altri. (1976).- Geografía física dels Països Catalans. Edit Ketres, 205 pàgines. Barcelona. 